\title{
Oropharyngeal Cancer pNO TNM Finding v6 and v7
}

National Cancer Institute

\section{Source}

National Cancer Institute. Oropharyngeal Cancer pNO TNM Finding v6 and v7. NCI

Thesaurus. Code C64608.

Oropharyngeal cancer with no metastasis to regional lymph nodes. (from AJCC 6th and 7th Eds.) 